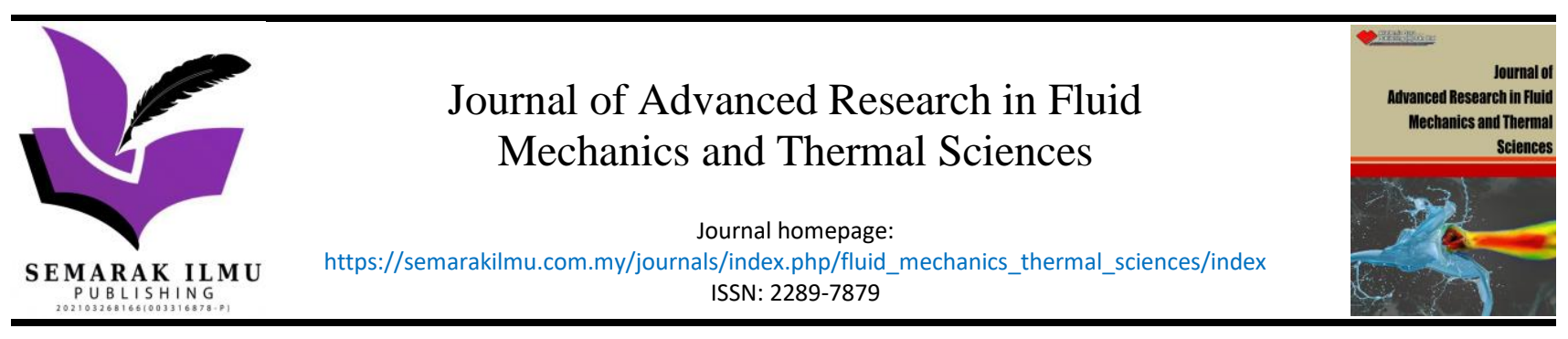

\title{
Numerical Study of a Basin Type Solar Still with a Double Glass Cover Under Winter Conditions
}

\author{
Azzedine Nahoui ${ }^{1}$, Redha Rebhi ${ }^{2,3}$, Giulio Lorenzini ${ }^{4,},{ }^{*}$, Younes Menni ${ }^{5}$ \\ Department of Physics (Laboratory LPCM), Faculty of Sciences, University of Mohamed Boudiaf, Msila, Algeria \\ University of Medea, Faculty of Technology, Department of Mechanical Engineering, Medea, 26000, Algeria \\ LERM - Renewable Energy and Materials Laboratory, University of Medea, Medea, 26000, Algeria \\ Department of Engineering and Architecture, University of Parma, Parco Area delle Scienze, 181/A, Parma 43124, Italy \\ Department of Technology, University Centre of Naama, P.O. Box 66, Naama 45000, Algeria
}

\section{ARTICLE INFO ABSTRACT}

\section{Article history:}

Received 14 July 2021

Received in revised form 17 September 2021

Accepted 19 September 2021

Available online 11 October 2021

\section{Keywords:}

Numerical study; solar still; double glass cover; solar radiation; winter conditions; wind speed; ambient temperature

\begin{abstract}
A numerical analysis of a basin-type solar still with a double glass cover is done under winter circumstances of solar radiation, ambient temperature, and wind speed. Equations defining thermal balances of different components of traditional and double glass cover solar stills are used to describe the physical issue, which is then solved using the Gauss-Seidel numerical technique. The effects of solar radiation, ambient temperature, and wind speed on the daily production, internal efficiency, and overall performance of solar stills are calculated and illustrated. The findings demonstrate that a solar still with a double-glass cover is more productive and efficient than a solar still with a single glass cover.
\end{abstract}

\section{Introduction}

Drought and an increase in water consumption across our world, whether by individuals or industrialists, has left mankind with a serious problem: it is no longer able to satisfy their demands [1]. Faced with this challenge, many initiatives have been made in the recent past, including seawater desalination and brackish water distillation [2-4]. Solar distillation has grown in popularity in recent years $[3,4]$. The usage of this energy source is based on two goals: a safe energy source and rigorous environmental adherence [5,6]. Despite its high operational costs, scientific interest in this renewable, clean, and limitless energy is growing [7]. Solar stills are improving in performance and becoming more competitive than conventional distillation methods thanks to scientific study [8].

This issue has been mentioned in a number of research, as seen in Table 1 . To solve the disadvantages of traditional solar distillation systems, An et al., [9] proposes an improved solar distillation system that combines concentrating optical engineering and nanofluid-based spectrum splitting PV/T technology. They discovered that the spectrum properties of nanofluid had a substantial impact on the improved distillation system's performance.

\footnotetext{
* Corresponding author.

E-mail address: Giulio.lorenzini@unipr.it
}

https://doi.org/10.37934/arfmts.88.1.3548 


\section{Table 1}

The most current solar distillation treatment studies

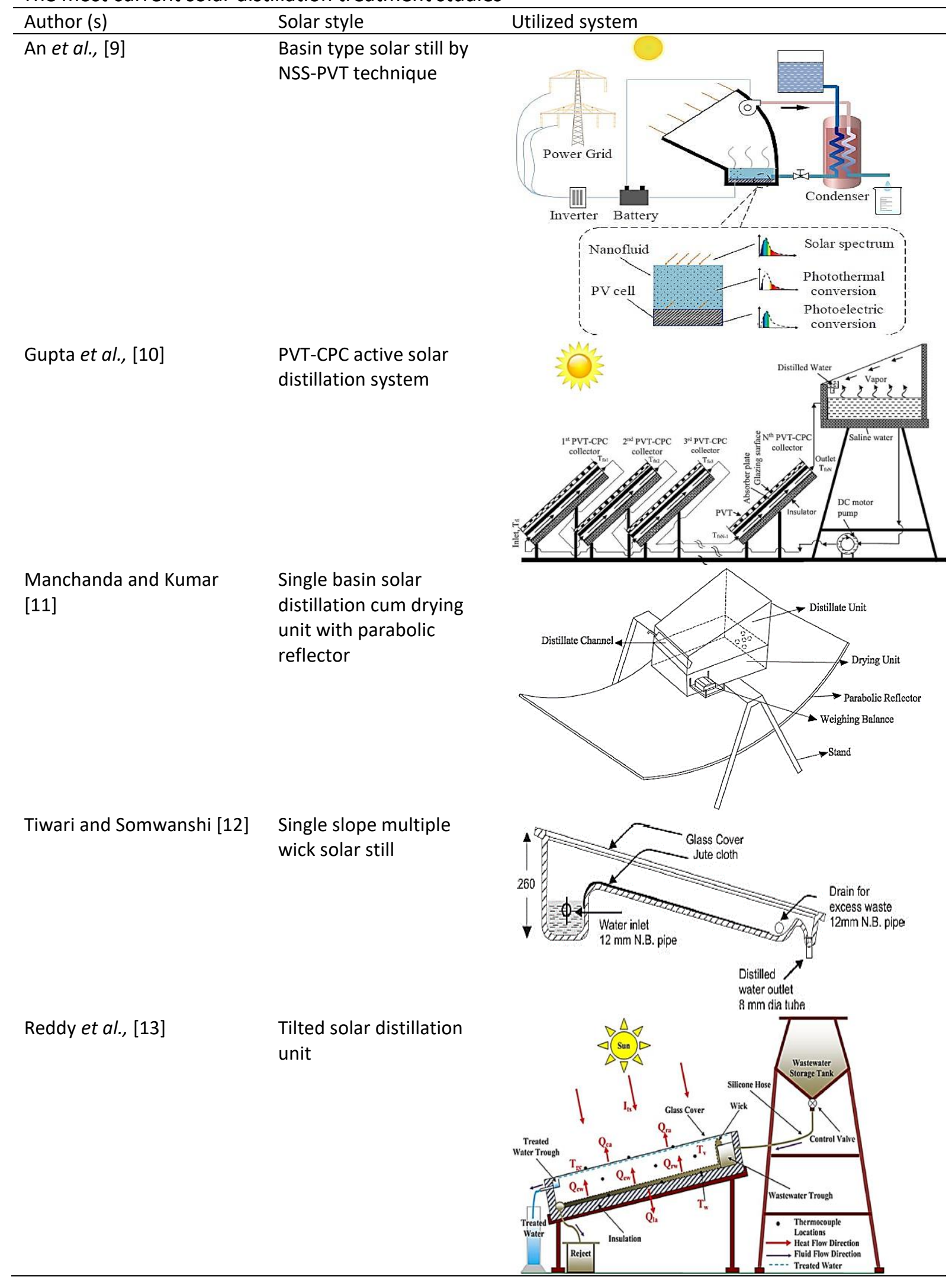




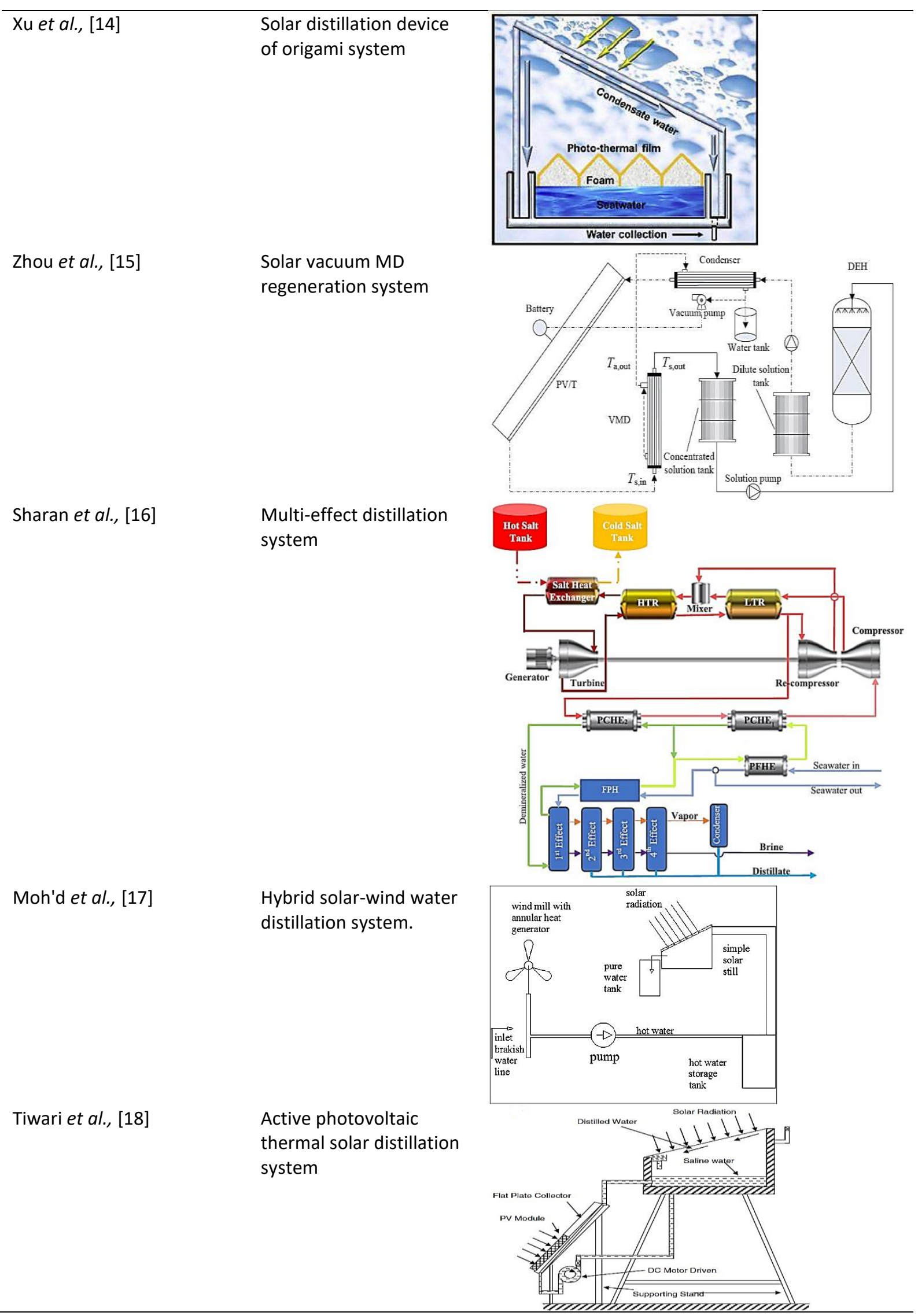




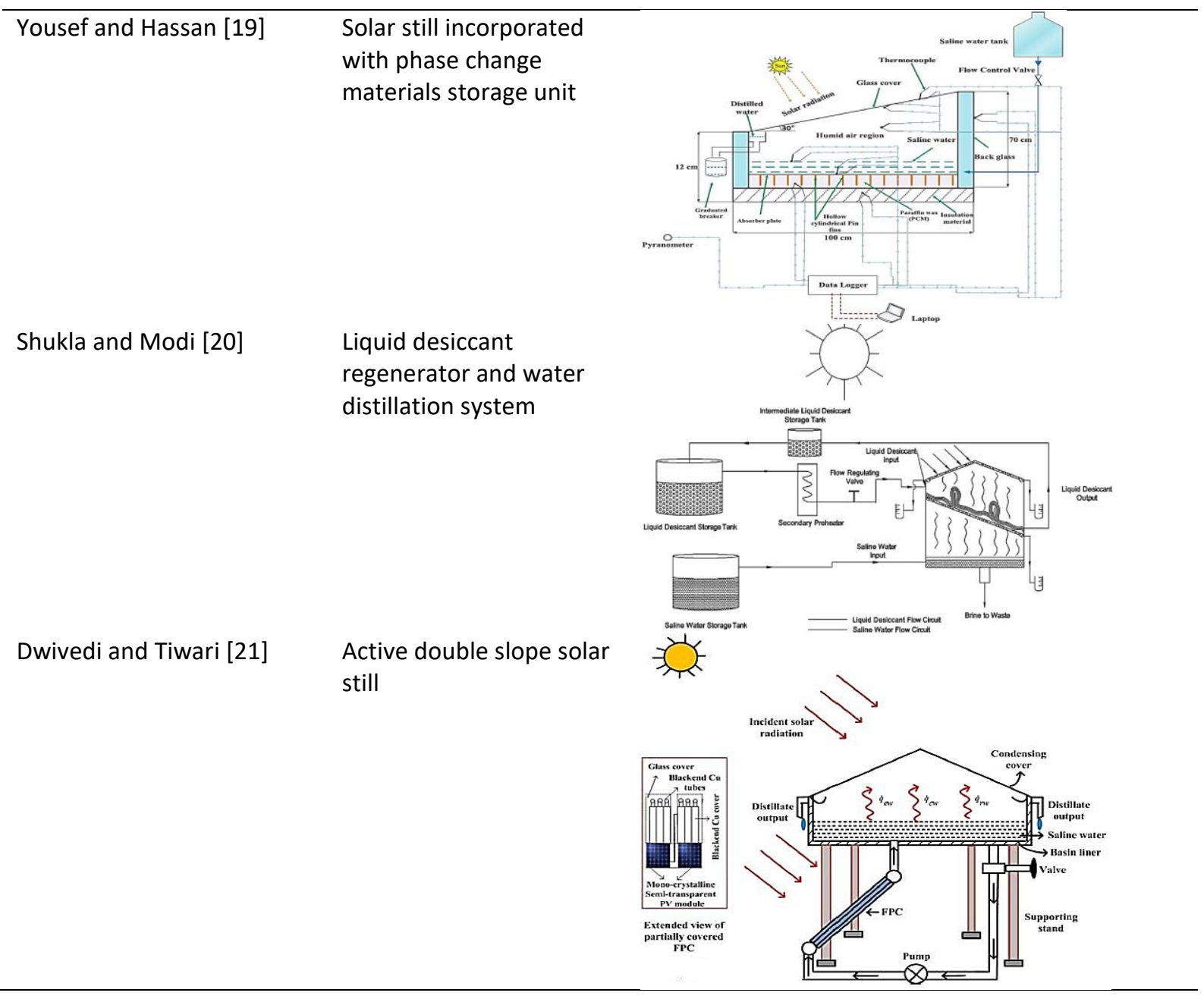

Gupta et al., [10] is working on developing an analytic properties equation for a completely identical $\mathrm{N}$ totally covered compound photo-thermal compound that is comparable to an integrated solar distillation system, analogous to the Hottel-Whillier-Bliss equation for a flat plate collector. The heat loss from the distillation unit basin was used to dry ginger in a drying chamber connected to the bottom of the distillation unit in Manchanda's research [11]. The tests were carried out using a parabolic reflector and a single-slope single-basin distillation and drying equipment. At lower water depths, the energy efficiency and total stress of distillation are shown to be greater. Tiwari and Somwanshi [12] provided a cost-benefit analysis of two small distillation units and a fountain tank intended to fulfill Jodhpur's 300-liter-per-day drinking water demand (India). The suggested station would be ideal for a location with plenty of brackish (impure) water, such as a river, lake, channel, or pond. A research by Reddy et al., [13] proposes treating RO reject and household sewage water in a single step using an indigenously built slanted solar distillation machine. Based on experimental observations, the unit's behavior, features, treated water quality, environmental advantages, and economics have been documented. The results obtained from their study confirm solar distillation as an efficient and sustainable option for wastewater treatment.

For emergency solar water purification, Xu et al., [14] create origami as photo-thermal materials based on common pen and paper. The pencil cartridge ripped into tiny sheets of graphite as a result of the drawing process, which broke the van der Waals interaction between the layers of graphite. Broadband absorption for solar energy collecting and good hydrophobic resistance to water transfer have been shown using paper fibers coupled with graphite sheets. In comparison to the flat system, the origami structure has efficiently enhanced solar energy consumption by boosting solar energy 
absorption area and minimizing solar reflection loss. For a liquid desiccant air conditioning system, Zhou et al., [15] presented a unique solar vacuum membrane distillation regeneration. Based on the heat and mass balance, they developed a mathematical model of the VMD regeneration process and the standard thermal regeneration method. When the air temperature is less than $32{ }^{\circ} \mathrm{C}$, the moisture content is greater than $19 \mathrm{~g} / \mathrm{kg}$, and the air flow velocity is less than $0.13 \mathrm{~kg} / \mathrm{s}$, the impact of VMD solution regeneration is superior to that of traditional heat regenerated.

According to Sharan's et al., [16] findings, the best storage tank design lowers distillate costs by 19 percent and raises the multi-effect distillation capacity factor from 46.4 percent to 75 percent. Cogeneration using the Brighton CSP-sCO $\mathrm{C}_{2}$ cycle was investigated at a number of coastal areas with strong solar resources. Their technical economic study revealed that the distillate generated by MED is 16 percent less expensive than the distillate produced by Yanbu's reverse osmosis technology. Moh'd et al., [17] suggested and investigated a hybrid solar and wind water distillation system. Their setup includes a traditional solar-powered basin as well as a wind-powered water heater. The suggested system has the benefit of being able to work at all hours of the day and night, allowing it to produce more distilled water even on overcast days with strong winds. Their findings revealed a substantial increase in distillate output, particularly on summer nights when wind energy is high. The impact of wind turbine size on system performance has also been investigated and recorded. According to their estimations, the output may be three to four times higher than that of traditional solar distillers. Others models, such as Tiwari et al., [18], Yousef and Hassan [19], Shukla and Modi [20], and Dwivedi and Tiwari [21] have lately been used in the presence of different experimental circumstances. Moreover, there are several studies that considered the heat transfer, solar energy, energy storage, etc, in channels and enclosures, and the following are just a few examples; Hassan et al., [22], Johnson et al., [23], Alawi and Kamar [24], Abdullah et al., [25], Lubis [26], Ghalambaz et al., [27,28], Hajjar et al., [29], Menni et al., [30-38,40], Menni and Azzi [39], Sakhri et al., [41,42], Bendjamaa et al., [43], Boursas et al., [44], etc.

The goal of this research is to find out how double glazing affects efficiency and solar-still output. Solar greenhouses have the benefit of being easy to construct and very inexpensive. The inclusion of second window is intended to boost the greenhouse effect in the solar still. A numerical analysis of solar still with and without a double glass cover is carried out in this context. The research is based on solar still component thermal balances and an iterative Gauss-Seidel calculation technique $[8,45$ 47]. For winter weather conditions, an ambient temperature of $12^{\circ} \mathrm{C}$ and a wind speed of $5 \mathrm{~m} / \mathrm{s}$, the impacts of solar radiation on daily distilled water production, overall and internal efficiency will be investigated. In this experiment, we use two solar stills, one conventional and the other with a double glass cover, both of which are practically the same in terms of glass, water and basin.

\section{Methodology}

\subsection{Solar Stills Under Investigation}

Figure 1 depicts internal and external heat transfers in conventional and double-glass cover solarstills. 


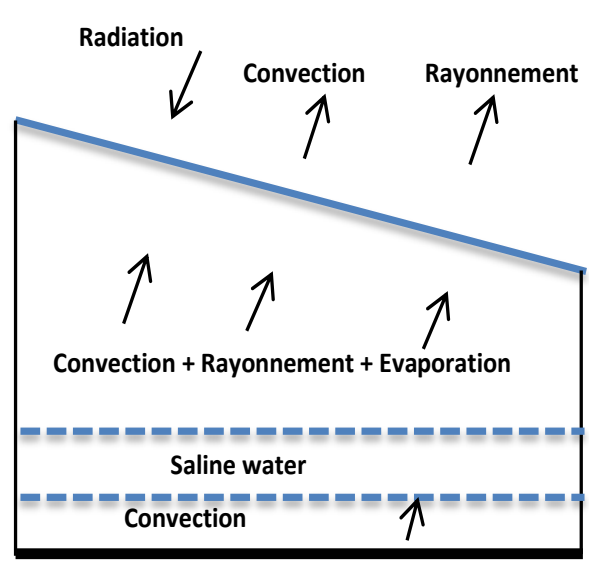

(a)

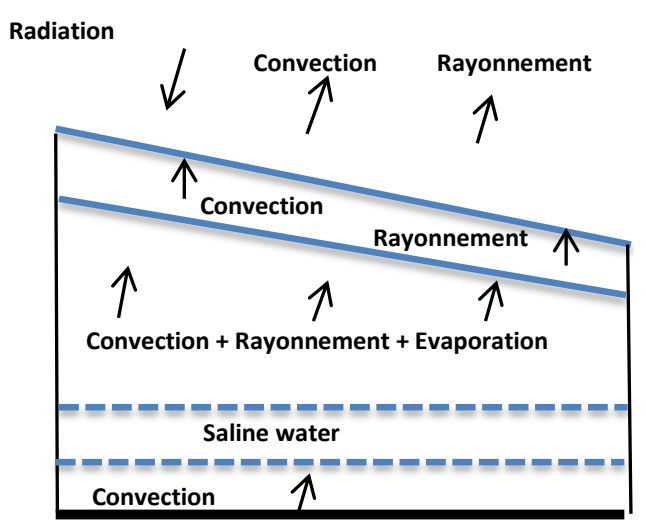

(b)

Fig. 1. Heat transfers in (a) conventional and (b) double glass cover solar stills

\subsection{Assumptions}

Equations defining thermal balances of various components of traditional and double glass cover solar stills are used to describe the physical issue, which is then solved using the Gauss-Seidel numerical technique.

We suggest the following simplification assumptions to minimize the mathematical heaviness

i. Steady heat transfer process;

ii. Heat loss of insulation is negligible;

iii. Only the glass cover is affected by condensation;

iv. There is no temperature gradient along the water mass depth; and

v. The solar still does not have any vapor leakage.

\subsection{Thermal Balance of Conventional Solar-Still}

The following are the constant thermal equations for glass-cover, water and basin [48]

$\alpha_{g} G+\Phi_{c-w-g}+\Phi_{r-w-g}+\Phi_{e v}-\Phi_{r-g-a}-\Phi_{c-g-a}=0$

$\tau_{g} \alpha_{w} G+\Phi_{c-b-w}-\Phi_{c-w-g}-\Phi_{r-w-g}-\Phi_{e v}-\Phi_{e x t}=0$

$\tau_{g} \tau_{w} \alpha_{b} G-\Phi_{c-b-w}=0$

In an explicit way, systems of equations become

$\alpha_{g} G+h_{w-g}^{c}\left(T_{w}-T_{g}\right)+h_{w-g}^{r}\left(T_{w}-T_{g}\right)+h_{w-g}^{e}\left(T_{w}-T_{g}\right)-h_{g-a}^{r}\left(T_{g}-T_{s}\right)-$ $h_{g-a}^{c}\left(T_{g}-T_{a}\right)=0$

$\tau_{g} \tau_{w} \alpha_{b} G-h_{b-w}^{c}\left(T_{b}-T_{w}\right)=0$

$\tau_{g} \alpha_{w} G+h_{b-w}^{c}\left(T_{b}-T_{w}\right)-h_{w-g}^{c}\left(T_{w}-T_{g}\right)-h_{w-g}^{r}\left(T_{w}-T_{g}\right)-h_{w-g}^{e}\left(T_{w}-T_{g}\right)-\left(\frac{\dot{m} C p_{w}}{A_{w}}\right)\left(T_{w}-\right.$ $\left.T_{a}\right)=0$ 


\subsection{Thermal Balance of Double Glass Cover Solar Still}

The steady thermal equations for first and second glass covers, water and basin can be written as follows [48]

$$
\begin{aligned}
& \alpha_{g} G+\Phi_{c-g 2-g 1}-\Phi_{c-g 1-a}-\Phi_{r-g 1-a}=0 \\
& \tau_{g} \alpha_{g} G+\Phi_{r-w-g 2}+\Phi_{c-w-g 2}+\Phi_{e v}-\Phi_{c-g 1-g 2}=0 \\
& \tau_{g} \tau_{g} \alpha_{w} G+\Phi_{c-b-w}-\Phi_{c-w-g 2}-\Phi_{r-w-g 2}-\Phi_{e v}-\Phi_{e x t}=0 \\
& \tau_{g} \tau_{w} \alpha_{b} G-\Phi_{c-b-w}=0
\end{aligned}
$$

In an explicit way, systems of equations become

$$
\begin{aligned}
& \alpha_{g} G+h_{g 2-g 1}^{c}\left(T_{g 2}-T_{g 1}\right)-h_{g 1-a}^{c}\left(T_{g 1}-T_{a}\right)-h_{g 1-a}^{r}\left(T_{g 1}-T_{s}\right)=0 \\
& \tau_{g} \alpha_{g} G+h_{w-g 2}^{r}\left(T_{w}-T_{g 2}\right)+h_{w-g 2}^{c}\left(T_{w}-T_{g 2}\right)+h_{w-g 2}^{e}\left(T_{w}-T_{g 2}\right)-h_{g 2-g 1}^{c}\left(T_{g 2}-T_{g 1}\right)=0 \\
& \tau_{g} \tau_{g} \alpha_{w} G+h_{b-w}^{c}\left(T_{b}-T_{w}\right)-h_{w-g 2}^{c}\left(T_{w}-T_{g 2}\right)-h_{w-g 2}^{r}\left(T_{w}-T_{g 2}\right)-h_{w-g 2}^{e}\left(T_{w}-T_{g 2}\right)- \\
& \left(\frac{\dot{m} C p_{w}}{A_{w}}\right)\left(T_{w}-T_{a}\right)=0 \\
& \tau_{g} \tau_{g} \tau_{w} \alpha_{b} G-h_{b-w}^{c}\left(T_{b}-T_{e}\right)=0
\end{aligned}
$$

\section{Results and Discussion}

A comparison between this new type of solar still and a traditional solar still is planned in order to examine the effects of solar radiation $(G)$, ambient temperature $\left(T_{a}\right)$, and wind velocity $(V)$ on daily output as well as overall $(\eta)$ and internal $\left(\eta_{i}\right)$ efficiency of a double glass cover solar still.

\subsection{Solar Radiation's Impact}

\subsubsection{Daily production}

Solar stills with single and double glass covers were tested on a daily basis (Figure 2). The findings show that the double glass cover has a beneficial impact on daily output; in fact, as solar radiation rises, the difference in daily production between conventional and double glass cover solar stills becomes significant. 


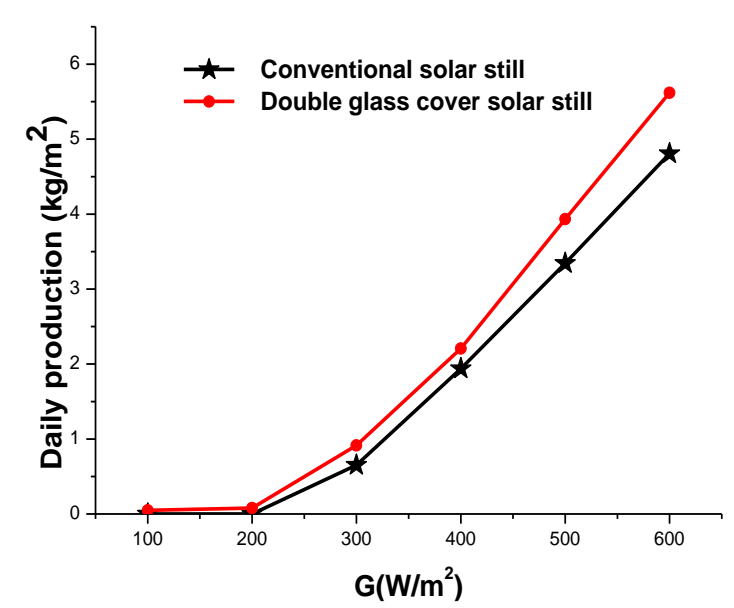

Fig. 2. Solar radiation's impact $(\mathrm{G})$ on daily production, $\mathrm{T}_{\mathrm{a}}=12^{\circ} \mathrm{C}$ and $\mathrm{V}=5 \mathrm{~m} / \mathrm{s}$

\subsubsection{Overall efficiency}

The impact of solar radiation on overall efficiency is seen in Figure 3. Indeed, the overall efficiency of a double glass cover solar still is significantly higher than that of a conventional solar still, with a difference between the two distributions that continues to grow in favor of the double glass cover still as the radiation increases.

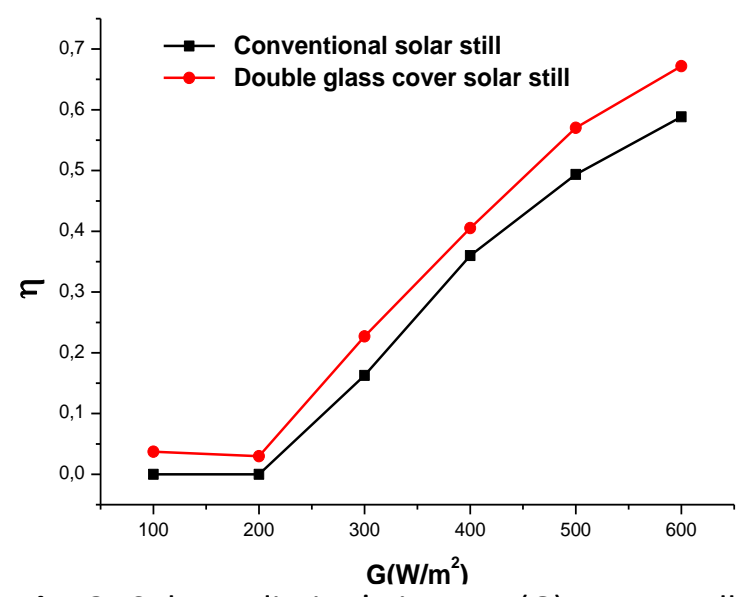

Fig. 3. Solar radiation's impact $(G)$ on overall efficiency $(\eta), T_{a}=12{ }^{\circ} \mathrm{C}$ and $V=5 \mathrm{~m} / \mathrm{s}$

\subsubsection{Internal efficiency}

The influence of solar radiation on the internal efficiency of conventional and double glass cover solar stills is depicted in Figure 4. In reality, when solar radiation improves, the internal efficiency distributions of the double glazed and conventional stills both grow, with the difference between the two distributions increasing in favor of the double glazing. 


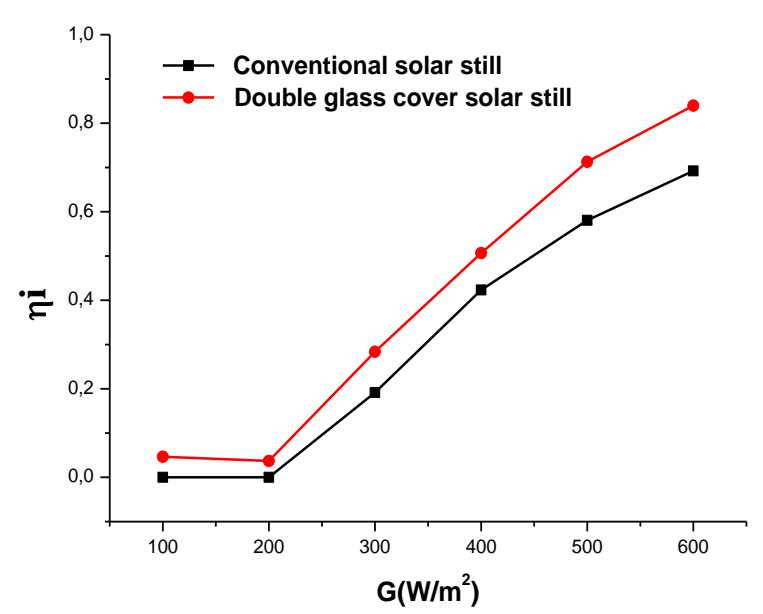

Fig. 4. Solar radiation's impact $(G)$ on internal efficiency $\left(\eta_{i}\right), T_{a}=12^{\circ} \mathrm{C}$ and $V=5 \mathrm{~m} / \mathrm{s}$

\subsection{Ambient Temperature's Impact}

\subsubsection{Daily production}

As shown in Figure 5, the daily production of a double glass cover solar still is significantly larger than that of a traditional solar still, with the difference between the two plots decreasing as the ambient temperature enhances.

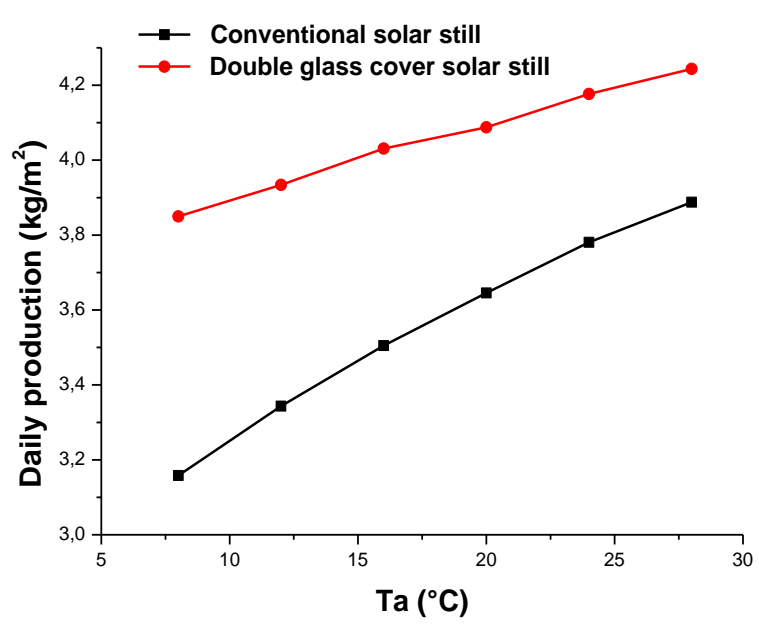

Fig. 5. Ambient temperature's impact $\left(T_{a}\right)$ on daily production in distilled water, $\mathrm{G}=500$ $\mathrm{W} / \mathrm{m}^{2}$ and $\mathrm{V}=5 \mathrm{~m} / \mathrm{s}$

\subsubsection{Overall efficiency}

The double glass cover solar still has a considerably greater overall efficiency than a traditional solar still, as seen in Figure 6 The overall efficiency of the improved system fluctuates slowly when compared to traditional system, and the difference between the two distributions decreases as the ambient temperature improves. 


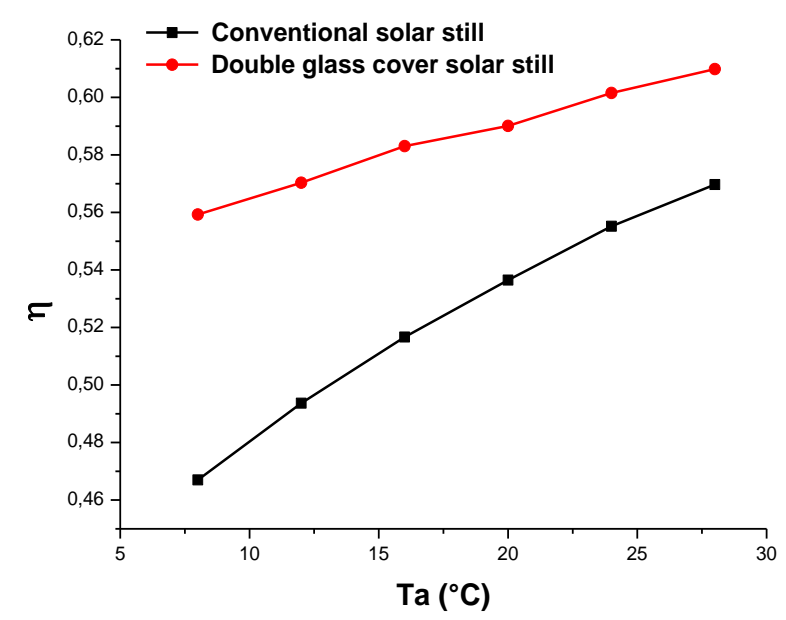

Fig. 6. Ambient temperature's impact $\left(T_{a}\right)$ on overall efficiency $(\eta), G=500 \mathrm{~W} / \mathrm{m}^{2}$ and $V=5 \mathrm{~m} / \mathrm{s}$

\subsubsection{Internal efficiency}

Figure 7 shows how the two stills behave in the situation of internal efficiency, which is comparable to the case of overall efficiency. It's worth noting that the internal efficiency values of the two stills are significantly greater than the overall efficiency, which is consistent with the mathematical formulae for the sun distillation phenomena.

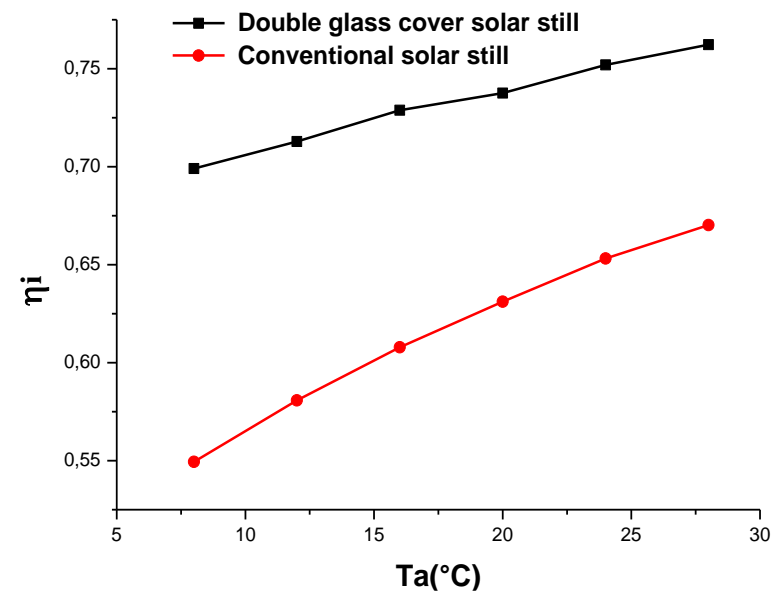

Fig. 7. Ambient temperature's impact $\left(T_{a}\right)$ on internal efficiency $\left(\eta_{i}\right), G=500 \mathrm{~W} / \mathrm{m}^{2}$ and $V=$ $5 \mathrm{~m} / \mathrm{s}$

\subsection{Solar Radiation's Impact on Temperatures}

\subsubsection{In conventional solar still}

Figure 8 demonstrates that the basin (absorber) and water temperatures are identical. This may be explained by the fact that the basin's thermal insulation is excellent ( $2^{\text {nd }}$ assumption); it only heats the bulk of water, resulting in their temperatures being well confused. However, it is evident that the temperature differential between the masse of water and the temperature of the glass cover grows as solar radiation enhances. 


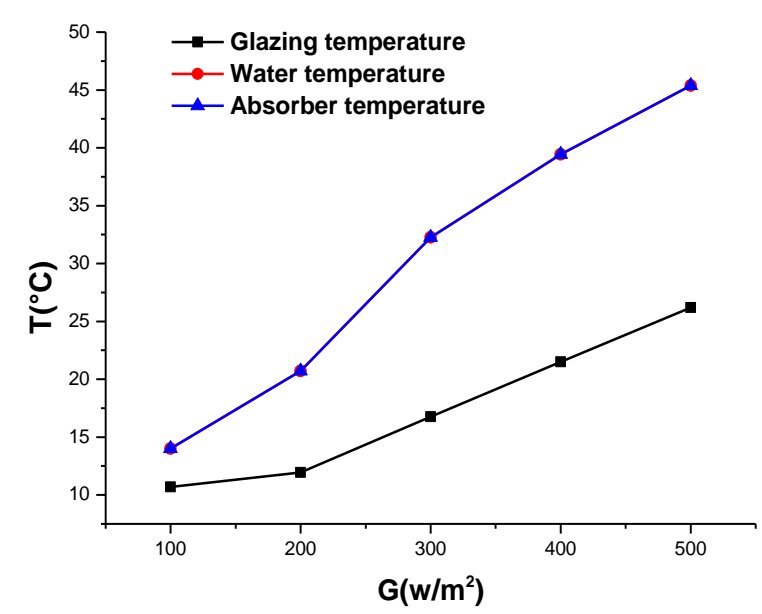

Fig. 8. Effect of solar radiation (G) on temperatures $(\mathrm{T})$ in conventional solar still, $\mathrm{T}_{\mathrm{a}}=$ $12^{\circ} \mathrm{C}$ and $\mathrm{V}=5 \mathrm{~m} / \mathrm{s}$

\subsubsection{In double glass cover solar still}

Figure 9 depicts the distribution of water and basin temperatures as a function of incident solar radiation. Furthermore, as a result of solar radiation, the temperature difference between the interior glass cover and the water continues to rise. It's also noting that the temperature of the basin rises with solar radiation, and the temperature distribution of exterior glass cover is perfectly identical to that of a traditional solar still.

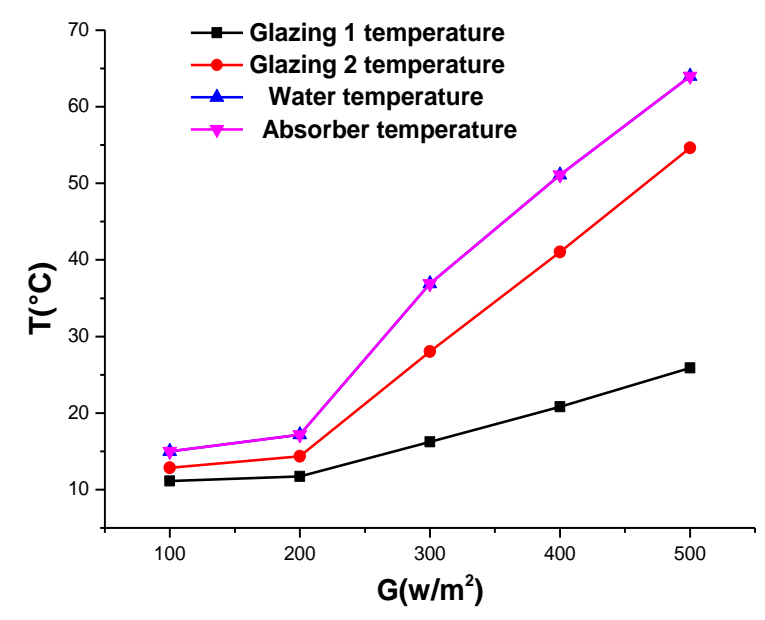

Fig. 9. Effect of solar radiation (G) on temperatures $(\mathrm{T})$ in double glass cover solar still, $\mathrm{T}_{\mathrm{a}}=12^{\circ} \mathrm{C}$ and $\mathrm{V}=5 \mathrm{~m} / \mathrm{s}$

\section{Conclusions}

The effects of solar radiation, ambient temperature and wind velocity on the performance of conventional and double glass cover solar stills are investigated numerically. The study focused on the equilibrium equations of various components of stills, with the Gauss-Seidel approach being used to calculate the solution numerically. The findings obtained have indicated that the double glass cover solar still is superior in terms of daily production, overall and internal efficiency than the 
traditional solar still under so-called winter circumstances when the distribution phenomena become virtually impossible.

Future studies in the scope of solar distillation can be carried out by presenting a comparison of different types of solar distillates such as: single-acting distillation, single slope still, double slope still, spherical still, cylinder still, conical still, multi-stage hair film distiller, multi-story still, etc. In addition to solar radiation, ocean temperature, and wind velocity, there are other factors such as operating conditions and geographic location affect the productivity of the solar distillation. It can check the extent of insulation of the internal and external surfaces of the distiller, thickness of the brine strip, the physical properties of the walls, the slope of the glass on the horizontal surface, the height of the brine level in the distiller, the distance that divides the free surface into two collectors, the characteristics of the components of the solar still, etc.

\section{References}

[1] Kabeel, A. E., Z. M. Omara, F. A. Essa, and A. S. Abdullah. "Solar still with condenser-A detailed review." Renewable and Sustainable Energy Reviews 59, no. C (2016): 839-857. https://doi.org/10.1016/j.rser.2016.01.020

[2] Haddad, Zakaria, Abla Chaker, and Ahmed Rahmani. "Improving the basin type solar still performances using a vertical rotating wick." Desalination 418 (2017): 71-78. https://doi.org/10.1016/j.desal.2017.05.030

[3] Dunglas, Jean. "Le dessalement de l'eau de mer, une nouvelle méthode pour accroitre la ressource en eau." Groupe eau. Académie d'agriculture de France (2014).

[4] Maurel, Alain. Dessalement de l'eau de mer et des eaux saumâtres et autres procédés non conventionnels d'approvisionnement en eau douce. Éditions Tec \& Doc, 2006.

[5] Velmurugan, V., M. Gopalakrishnan, R. Raghu, and K. Srithar. "Single basin solar still with fin for enhancing productivity." Energy Conversion and Management 49, no. $10 \quad$ (2008): 2602-2608. https://doi.org/10.1016/i.enconman.2008.05.010

[6] Shukla, S. K., and V. P. S. Sorayan. "Thermal modeling of solar stills: an experimental validation." Renewable Energy 30, no. 5 (2005): 683-699. https://doi.org/10.1016/i.renene.2004.03.009

[7] Abu-Arabi, Mousa, Yousef Zurigat, Hilal Al-Hinai, and Saif Al-Hiddabi. "Modeling and performance analysis of a solar desalination unit with double-glass cover cooling." Desalination 143, no. 2 (2002): $173-182$. https://doi.org/10.1016/S0011-9164(02)00238-2

[8] Fatani, A. A., G. M. Zaki, and A. Al-Turki. "Improving the yield of simple basin solar stills as assisted by passively cooled condensers." Renewable Energy 4, no. 4 (1994): 377-386. https://doi.org/10.1016/0960-1481(94)90044-2

[9] An, Wei, Lu Chen, Tao Liu, and Yao Qin. "Enhanced solar distillation by nanofluid-based spectral splitting PV/T technique: Preliminary experiment." Solar Energy $176 \quad$ (2018): $146-156$. https://doi.org/10.1016/i.solener.2018.10.029

[10] Gupta, Vidya Sagar, Desh Bandhu Singh, R. K. Mishra, Sanjeev Kumar Sharma, and G. N. Tiwari. "Development of characteristic equations for PVT-CPC active solar distillation system." Desalination 445 (2018): $266-279$. https://doi.org/10.1016/i.desal.2018.08.009

[11] Manchanda, Himanshu, and Mahesh Kumar. "Performance analysis of single basin solar distillation cum drying unit with parabolic reflector." Desalination 416 (2017): 1-9. https://doi.org/10.1016/i.desal.2017.04.020

[12] Tiwari, Anil Kr, and Aneesh Somwanshi. "Techno-economic analysis of mini solar distillation plants integrated with reservoir of garden fountain for hot and dry climate of Jodhpur (India)." Solar Energy 160 (2018): 216-224. https://doi.org/10.1016/i.solener.2017.11.078

[13] Reddy, K. S., H. Sharon, D. Krithika, and Ligy Philip. "Performance, water quality and enviro-economic investigations on solar distillation treatment of reverse osmosis reject and sewage water." Solar Energy 173 (2018): 160-172. https://doi.org/10.1016/i.solener.2018.07.033

[14] Xu, Ying, Jiaxiang Ma, Dongqing Liu, Hongbo Xu, Fuyi Cui, and Wei Wang. "Origami system for efficient solar driven distillation in emergency water supply." Chemical Engineering Journal 356 (2019): 869-876. https://doi.org/10.1016/j.cej.2018.09.070

[15] Zhou, Junming, Xiaosong Zhang, Bo Sun, and Wei Su. "Performance analysis of solar vacuum membrane distillation regeneration." $\quad$ Applied $\quad$ Thermal $\quad$ Engineering $144 \quad$ (2018): https://doi.org/10.1016/j.applthermaleng.2018.08.052

[16] Sharan, Prashant, Ty Neises, Joshua Dominic McTigue, and Craig Turchi. "Cogeneration using multi-effect distillation and a solar-powered supercritical carbon dioxide Brayton cycle." Desalination 459 (2019): 20-33. https://doi.org/10.1016/i.desal.2019.02.007 
[17] Moh'd A, Al-Nimr, Suhil M. Kiwan, and Samer Talafha. "Hybrid solar-wind water distillation system." Desalination 395 (2016): 33-40. https://doi.org/10.1016/i.desal.2016.05.018

[18] Tiwari, G. N., J. K. Yadav, D. B. Singh, I. M. Al-Helal, and Ahmed Mahmod Abdel-Ghany. "Exergoeconomic and enviroeconomic analyses of partially covered photovoltaic flat plate collector active solar distillation system." Desalination 367 (2015): 186-196. https://doi.org/10.1016/j.desal.2015.04.010

[19] Yousef, Mohamed S., and Hamdy Hassan. "Energetic and exergetic performance assessment of the inclusion of phase change materials (PCM) in a solar distillation system." Energy Conversion and Management 179 (2019): 349361. https://doi.org/10.1016/i.enconman.2018.10.078

[20] Shukla, Dhruvin L., and Kalpesh V. Modi. "Hybrid solar still-Liquid desiccant regenerator and water distillation system." Solar Energy 182 (2019): 117-133. https://doi.org/10.1016/i.solener.2019.02.043

[21] Dwivedi, V. K., and G. N. Tiwari. "Experimental validation of thermal model of a double slope active solar still under natural circulation mode." Desalination 250, no. 1 (2010): 49-55. https://doi.org/10.1016/i.desal.2009.06.060

[22] Hassan, Zulkurnain, Mohd Suffian Misaran@Misran, Nancy Julius Siambun, Ag Sufiyan Abd Hamid, and Mohd Amran Madlan. "Feasibility of using Solar PV Waste Heat to Regenerate Liquid Desiccant in Solar Liquid Desiccant Air Conditioning System." Journal of Advanced Research in Experimental Fluid Mechanics and Heat Transfer 2, no. 1 (2020): 10-16.

[23] Johnson, Zwalnan Selfa, Abakar Yousif Abdalla, Shanmugam Anandan, Chan Andy Tak-Yee, and Su Yuehong. "A Numerical Evaluation of the Effect of Building Thermal Load on the Overall Performance Characteristic of a GridCoupled PV/T Energy System." Journal of Advanced Research in Numerical Heat Transfer 4, no. 1 (2021): 32-43.

[24] Alawi, Omer A., and Haslinda Mohamed Kamar. "Performance of Solar Thermal Collector Using Multi-Walled Carbon Nanotubes: Simulation Study." Journal of Advanced Research in Micro and Nano Engineering 2, no. 1 (2020): 12-21.

[25] Abdullah, Amira Lateef, Suhaimi Misha, Noreffendy Tamaldin, Mohd Afzanizam Mohd Rosli, and Fadhil Abdulameer Sachit. "Numerical analysis of solar hybrid photovoltaic thermal air collector simulation by ANSYS." CFD Letters 11, no. 2 (2019): 1-11.

[26] Lubis, Hamzah. "Renewable Energy of Rice Husk for Reducing Fossil Energy in Indonesia." Journal of Advanced Research in Applied Sciences and Engineering Technology 11, no. 1 (2018): 17-22.

[27] Ghalambaz, Mohammad, Seyed Mohsen Hashem Zadeh, S. A. M. Mehryan, loan Pop, and Dongsheng Wen. "Analysis of melting behavior of PCMs in a cavity subject to a non-uniform magnetic field using a moving grid technique." Applied Mathematical Modelling 77 (2020): 1936-1953. https://doi.org/10.1016/i.apm.2019.09.015

[28] Ghalambaz, M., T. Groşan, and I. Pop. "Mixed convection boundary layer flow and heat transfer over a vertical plate embedded in a porous medium filled with a suspension of nano-encapsulated phase change materials." Journal of Molecular Liquids 293 (2019): 111432. https://doi.org/10.1016/j.molliq.2019.111432

[29] Hajjar, Ahmad, S. A. M. Mehryan, and Mohammad Ghalambaz. "Time periodic natural convection heat transfer in a nano-encapsulated phase-change suspension." International Journal of Mechanical Sciences 166 (2020): 105243. https://doi.org/10.1016/j.ijmecsci.2019.105243

[30] Menni, Younes, Ali J. Chamkha, and Ahmed Azzi. "Nanofluid flow in complex geometries-a review." Journal of Nanofluids 8, no. 5 (2019): 893-916. https://doi.org/10.1166/jon.2019.1663

[31] Menni, Younes, Ali J. Chamkha, and Ahmed Azzi. "Nanofluid transport in porous media: a review." Special Topics \& Reviews in Porous Media: An International Journal 10, no. 1 (2019): 49-64. https://doi.org/10.1615/SpecialTopicsRevPorousMedia.2018027168

[32] Menni, Younes, Ahmed Azzi, and Ali J. Chamkha. "A review of solar energy collectors: models and applications." Journal of Applied and Computational Mechanics 4, no. 4 (2018): 375-401.

[33] Menni, Younes, Ahmed Azzi, and Ali Chamkha. "Enhancement of convective heat transfer in smooth air channels with wall-mounted obstacles in the flow path." Journal of Thermal Analysis and Calorimetry 135, no. 4 (2019): 19511976. https://doi.org/10.1007/s10973-018-7268-x

[34] Menni, Younes, A. Chamkha, Chafika Zidani, and Boumédiène Benyoucef. "Baffle orientation and geometry effects on turbulent heat transfer of a constant property incompressible fluid flow inside a rectangular channel." International Journal of Numerical Methods for Heat \& Fluid Flow 30, no. 6 (2019): 3027-3052. https://doi.org/10.1108/HFF-12-2018-0718

[35] Menni, Younes, Ahmed Azzi, Ali J. Chamkha, and Souad Harmand. "Effect of wall-mounted V-baffle position in a turbulent flow through a channel: Analysis of best configuration for optimal heat transfer." International Journal of Numerical Methods for Heat \& Fluid Flow 29, no. 10 (2019): 3908-3937. https://doi.org/10.1108/HFF-06-2018-0270

[36] Menni, Younes, Ahmed Azzi, and A. Chamkha. "Modeling and analysis of solar air channels with attachments of different shapes." International Journal of Numerical Methods for Heat \& Fluid Flow 29, no. 5 (2019): 1815-1845. https://doi.org/10.1108/HFF-08-2018-0435 
[37] Menni, Younes, Ahmed Azzi, and Ali J. Chamkha. "Computational thermal analysis of turbulent forced-convection flow in an air channel with a flat rectangular fin and downstream v-shaped baffle." Heat Transfer Research 50, no. 18 (2019): 1781-1818. https://doi.org/10.1615/HeatTransRes.2019026143

[38] Menni, Younes, Ahmed Azzi, Ali J. Chamkha, and Souad Harmand. "Analysis of fluid dynamics and heat transfer in a rectangular duct with staggered baffles." Journal of Applied and Computational Mechanics 5, no. 2 (2019): 231248.

[39] Menni, Younes, and Ahmed Azzi. "Numerical analysis of thermal and aerodynamic fields in a channel with cascaded baffles." Periodica Polytechnica Mechanical Engineering 62, no. 1 (2018): 16-25. https://doi.org/10.3311/PPme.10613

[40] Menni, Y., A. Azzi, C. Zidani, and B. Benyoucef. "Numerical analysis of turbulent forced-convection flow in a channel with staggered I-shaped baffles." Journal of New Technology and Materials 6, no. 2 (2016): 44-55. https://doi.org/10.12816/0043933

[41] Sakhri, Nasreddine, Abdeljabar Moussaoui, Younes Menni, Milad Sadeghzadeh, and Mohammad Hosein Ahmadi. "New passive thermal comfort system using three renewable energies: Wind catcher, solar chimney and earth to air heat exchanger integrated to real-scale test room in arid region (Experimental study)." International Journal of Energy Research 45, no. 2 (2021): 2177-2194. https://doi.org/10.1002/er.5911

[42] Sakhri, Nasreddine, Draoui Belkacem, and Menni Younes. "Experimental study of earth to air heat exchanger performance in arid regions. First step: in-situ measurement of ground vertical temperature profile for different depths." Journal of Advanced Research in Fluid Mechanics and Thermal Sciences 56, no. 2 (2019): 183-194.

[43] Bendjamaa, I., T. Allaoui, Y. Menni, A. J. Chamkha, and E. Lorenzini. "Study and comparison between two receivers of parabolic trough collector." Mathematical Modelling of Engineering Problems 6, no. 3 (2018): $385-389$. https://doi.org/10.18280/mmep.060309

[44] Boursas, Abdelhakim, Mohamed Salmi, Giulio Lorenzini, Hijaz Ahmad, Younes Menni, Djamal Fridja, Rachid Chebbi et al. "Enhanced Heat Transfer by Oil/Multi-Walled Carbon Nano-Tubes Nanofluid." In Annales de Chimie-Science des Matériaux, vol. 45, no. 2, pp. 93-103. 2021. https://doi.org/10.18280/acsm.450201

[45] Zurigat, Yousef H., and Mousa K. Abu-Arabi. "Modelling and performance analysis of a regenerative solar desalination unit." Applied Thermal Engineering 24, no. 7 (2004): $1061-1072$. https://doi.org/10.1016/i.applthermaleng.2003.11.010

[46] Malik, M. AS, Gopal Nath Tiwari, Arun Kumar, and M. S. Sodha. Solar distillation (a practical study of a wide range of stills and their optimum design, construction, and performance). Pergamon Press, Oxford, 1982.

[47] Smakdji, Nafila. "Optimisation et modelisation d'un distillateur solaire a ailettes avec stockage de chaleur." PhD diss., Universite Mentouri Constantine (2014).

[48] Elango, C., N. Gunasekaran, and K. Sampathkumar. "Thermal models of solar still-a comprehensive review." Renewable and Sustainable Energy Reviews 47 (2015): 856-911. https://doi.org/10.1016/i.rser.2015.03.054 